DOI https://doi.org/10.18551/rjoas.2018-08.41

\title{
THE EFFECT OF SERVICE QUALITY ON CUSTOMER LOYALTY WITH CUSTOMER SATISFACTION AND TRUST AS THE INTERVENING VARIABLES AT PT BANK TABUNGAN NEGARA PERSERO TBK OF SURABAYA BRANCH OFFICE
}

\author{
Budistiawan Rozaq*, Suryani Tatik \\ Sekolah Tinggi IImu Ekonomi (STIE) Perbanas Surabaya, Indonesia \\ *E-mail: budistiawanrozaq@gmail.com \\ ORCID: 0000-0002-5641-3336
}

\begin{abstract}
The aims of this research were: to analyze the direct effect of service quality on customer loyalty, to analyze the indirect effect of service quality on customer loyalty with customer satisfaction as the intervening variable, and to analyze the indirect effect of service quality on customer loyalty with customer trust as the intervening variable. This research tested the hypothesis that was intended to strengthen the theory applied as the reference material. Quantitative approach was applied in this research. The population of this research was all customers of BTN of Surabaya Branch Office. The researchers took a sample of 200 customers. Based on the research findings, it was found that the service quality had a direct effect with a significant and positive result on customer loyalty that could be used as a reference by BTN to better maintain and improve its services. Customer of BTN of Surabaya Branch Office commonly felt satisfied with the provided services. However, the satisfaction was derived from the service quality so that customer loyalty in this research showed insignificant result. Meanwhile, the effect of service quality on customer loyalty mediated by customer trust showed significant and positive result which meant that the trust obtained from good service quality provided by BTN of Surabaya Branch Office truly gave positive effect on customer loyalty.
\end{abstract}

\section{KEY WORDS}

Service, quality, loyalty, satisfaction, trust.

In the modern world, to promote the economy of a country, the role of banking services is very large and also important. Banking institutions are the core of financial system of a country (Hermansyah, 2009). Almost all sectors dealing with financial activities always need bank services. In the banking business, the quality of service is very important. In addition to diversity, a wide range of products are offered, improvements in information technology, physical services, and non-physical services are intended to improve service quality (Ariyani, 2008).

Customer assessment of the bank is affected by how customers interpret the bank products or services they receive. Providing high quality service is a must to achieve customer satisfaction and it must be carried out (Bedi, 2010). To the customers, the service quality and customer satisfaction come from an organized service in which customers will directly receive the services from the banking institutions. Customer loyalty will be a true financial source because it costs efficiently compared to having to find new customers which will cost up to five times greater. Encouraging customer desires to use bank products and services and establishing close relationships with customers is a real challenge to banking services (Suhardi, 2006).

In choosing banking services, especially in saving the funds the customers own to avoid the risk of loss due to poor performance of a bank, customers are now becoming smarter and more selective. The element of trust is indeed a major factor. Trust will also be needed to build and maintain long-term relationships (Akbar and Parves, 2009). Long-term business continuity is based on a high customer commitment to a bank.

The dynamics of the situation and conditions on external factors in the context of marketing of banking services should be a business opportunity to generate profit or benefit 
and also to maintain the existence of the bank. For the sake of the smoothness of the matter, the bank is required to continuously adjust the products and services to the needs of the customers. The quality of products and services, which is in accordance with the customer desires, determines the level of customer satisfaction. There are two main things that are closely related between the customer satisfaction and the provided service that is the customer expectation of service quality and customer perception on service quality. Customers will be satisfied if the performance on the products and services exceeds their expectations.

Commonly, customers will be satisfied if they are served properly by the bank employees. Therefore, the bank must place the customer as king in its service. It is important for banks to learn how customers behave, what customers want and how to serve the customers well and excellently. Services provided in serving the customer must be in accordance with the banking etiquette that is the procedure to serve the customer well according to Kashmir (2004).

Customer satisfaction obtained by customers directly or indirectly affects the bank image which will also affect the increase of NOA (Number of Account) and VOA (Volume of Account) and will contribute directly and positively to Bank Tabungan Negara. In such a situation, the bank must put customer satisfaction above all to obtain customer empathy so that customers who have joined Bank Tabungan Negara will have an increasing level of loyalty.

Interpersonal relationship has been proven to be an obstacle for the customers to move to another bank (Suryani, 2006). The research findings from a research conducted by Molina et al. (2007) revealed that belief has a dominant effect on loyalty. The development of the banking industry in Indonesia, that is increasingly tough and high, especially coupled with the development of global banking conditions in which the market has been able to access the domestic market, the effort in terms of modeling the trust and customer satisfaction can be a weapon that can be used by each bank to compete with each other maximally and it will also be able to produce more value that is very useful for its customers.

The aims of this research were: 1) to analyze the direct effect of service quality on customer loyalty, 2) to analyze the indirect effect of service quality on customer loyalty with customer satisfaction as the intervening variable, and 3) to analyze the indirect effect of service quality on customer loyalty with customer trust as the intervening variable.

\section{METHODS OF RESEARCH}

This research tested the hypothesis that was intended to strengthen the theory applied as the reference material. A quantitative approach was applied in this study in which it used a post-positivist paradigm (such as thoughts about cause and effect, reduction on the variables, hypotheses and specific questions, the use of measurement and observation, and theory testing) in developing science. This quantitative approach applied some strategies consisting of experiment and survey that required statistical data. Based on the depth of the research, this research could be categorized as explanative research because it correlated between cause and effect that occurred between the variables under the research. Based on the data type, this research could be classified as field research.

Population, Sample and Sampling Technique. The population of this research was all customers of BTN of Surabaya Branch Office. The researchers took a sample of 200 customers of BTN of Surabaya Branch Office in which according to Hair et al. (2010) the number of samples (observational data) is at least 5 times of the parameters to be estimated or at least one hundred people. The researchers determined the criteria that had been determined in advance by using purposive sampling technique. The technique in taking the sample was called the sampling technique. The sampling technique used in this research was purposive sampling technique. According to Suharyadi (2011), purposive sampling technique is the selection of non-random samples in which the sample is selected based on certain considerations. 
Data Analysis Technique. Sugiyono (2012) mentioned that data analysis technique on quantitative research use statistics. According Sugiyono (2012), descriptive statistics are statistics used to analyze the data by describing or illustrating the data that have been collected without the intention to make a conclusion that applies for the public or to make a generalization. The data analysis of this research was performed by using classical assumption test, multiple linear regression analysis and hypothesis testing of intervening variables.

In this research, the researchers applied path analysis technique because there was an assumption that the variables of customer satisfaction and trust which affected the correlation between independent variable were the service quality to customer loyalty in BTN. The level of confidence used in this research was $95 \%$ and $\alpha$ was $5 \%$.

\section{RESULTS OF STUDY}

Data Normality Test. Data normality test is a classical assumption test that aims to test whether the regression model and residual data on the dependent and independent variables have a normal distribution or not.

Table 1 - Test Results of One Sample Kolmogorov-Smirnov

$\begin{array}{lll}\text { No } & \text { Description } & \text { Results } \\ 1 & \text { Mean } & 0.000 \\ 2 & \text { Std. Deviation } & 0.296 \\ 3 & \text { Test Statistics } & 0.815 \\ 4 & \text { Asymp. Sig. (2-tailed) } & 0.521\end{array}$

Based on Table 1, test results of one sample Kolmogorov-Smirnov, it showed that the value of Kolmogorov-Smirnov was 0.815 and the significance level of the test was 0.521 . It could be concluded that the regression model was normally distributed because of its significance value $>0.05$.

Multicollinearity Test. Multicollinearity test is a test performed to see whether or not there is a high correlation between the independent variables in a multiple linear regression model.

Table 2 - Results of Multicollinearity Test

$\begin{array}{llll}\text { No } & \text { Variables } & \text { Tolerance Value } & \text { VIF Value } \\ 1 & \text { SQ (Service Quality) } & 0.181 & 5.535 \\ 2 & \text { CS (Customer Satisfaction) } & 0.233 & 4.291 \\ 3 & \text { CT (Customer Trust) } & 0.236 & 4.242\end{array}$

Based on the results of multicollinearity test, the tolerance value $>0.10$ and VIF value $<$ 10 from each variable, hence model was free from multicollinearity assumption.

Multiple Regression Analysis. Based on the data processing using SPSS 16 software, it obtained the value of constants and regression coefficients as presented in Table 3 below:

Table 3 - Results of Regression Analysis (X Variable to Y Variable)

\begin{tabular}{|c|c|c|c|c|c|}
\hline $\mathrm{R}$ & R Square & & Adju & R Square & \\
\hline 0.803 & 0.644 & & 0.64 & & \\
\hline No & Variables & $\begin{array}{l}\text { Coefficient } \\
\text { Unstandardized }\end{array}$ & Standardized & $\mathrm{T}$ & Sig \\
\hline $\begin{array}{l}1 \\
2\end{array}$ & Constant & -0.513 & 0803 & -2.357 & 0.019 \\
\hline
\end{tabular}

Dependent Variable: (LY) Loyalty.

Based on the calculation of regression analysis in table 3, it obtained multiple linear regression equation as follows:

$$
Y=-0.513+1.104 X+e
$$


Based on the above regression equation, it obtained the effect of independent variable of service quality to dependent variable that is customer loyalty. There was a direct correlation of independent variable namely service quality to dependent variable namely customer loyalty. To know how big effect of independent variable to dependent variable that is customer loyalty, it could be seen from the regression coefficient value.

The coefficient value of the service quality variable $(X)$ was 1.104 in the positive direction. A positive sign meant that the independent variable had a direct change correlation with the dependent variable. If the service quality variable increases, the customer loyalty would also increase and vice versa if the service quality variable decreases then customer loyalty will also decrease.

Based on table 3 , it could be found out how much dependent variable could be explained by independent variable which could be seen from the coefficient of determination R2 ( $R$ Square) value that was equal to 0,644 . It meant that the independent variable of service quality affected customer loyalty by $64.4 \%$, while the $35.6 \%$ was affected by other variables outside the regression model.

Correlation coefficient $(R)$ could also be used to measure the closeness of a correlation between independent variable and independent variable. Based on the test results, it was known that the value of the correlation coefficient $(R)$ was 0.803 or $80.3 \%$. It proved that independent variables namely service quality had closeness correlation with customer loyalty as many as $80.3 \%$.

Path Analysis. Path analysis is an advanced level of regression analysis that gives the output or outcome of indirect influence of independent variable namely service quality to dependent variable consisting of customer loyalty through the intervening variable consisting of customer satisfaction and customer trust. Based on the calculation using SPSS 16 software, it was known that the result of path analysis test was as follows:

Table 4 - Results of Path Analysis Test

\begin{tabular}{|c|c|c|c|c|c|}
\hline \multirow{2}{*}{$\begin{array}{l}\mathrm{R} \\
0.840\end{array}$} & \multirow{2}{*}{ R Square } & & & \\
\hline & & \multicolumn{2}{|c|}{ Adjusted R Square } & & \\
\hline No & Variables & $\begin{array}{l}\text { Coefficient } \\
\text { Unstandardized }\end{array}$ & Standardized & $\mathrm{t}$ & Sig \\
\hline 1 & SQ (Service Quality) & 0.455 & 0.112 & 4.070 & 0.000 \\
\hline 2 & CS (Customer Satisfaction) & 0.110 & 0.084 & 1.297 & 0.196 \\
\hline 3 & CT (Customer Trust) & 0.550 & 0.086 & 6.373 & 0.000 \\
\hline
\end{tabular}

Dependent Variable: LY (Loyalty).

Table 4 showed the results of the path analysis. However, to know the indirect effect of independent variable consisting of service quality through intervening variable consisting of customer satisfaction and customer trust, it further affected customer loyalty. Based on the results of path analysis test, it could be concluded as follows:

The Effect of Service Quality on Customer Loyalty through Customer Satisfaction. Based on the results of path analysis, it was found that there was a direct correlation between the independent variable X (Service Quality) $\rightarrow Z$ (Customer Loyalty) as many as 0.331. Indirect correlation between $X$ (Service Quality) $\rightarrow$ Y1 (Customer Satisfaction) $\rightarrow Z$ (Customer Loyalty) was $0.803 \times 0.093=0.075$. Thus, the correlation value between the independent variable and the dependent variable was 0.075 . It meant that the customer satisfaction as the intervening variable could not be proved as an intervening variable because the total value of the indirect correlation of the independent variable $(X)$ through the intervening variable $(Y)$ to the dependent variable $(Z)$ was 0.075 which was less than the direct correlation of the independent variable $(X)$ to the dependent variable $(Z)$ of 0.331 .

The Effect of Service Quality on Customer Loyalty Mediated by Customer Trust. Based on the results of path analysis, it was found that there was a direct correlation between the independent variable $X$ (Service Quality) $\rightarrow Z$ (Customer Loyalty) as many as 0.331 . Indirect correlation between $X$ (Service Quality) $\rightarrow$ Y2 (Customer Trust) $\rightarrow Z$ (Customer Loyalty) was $0.803 \times 0.454=0.365$. Thus, the correlation value between the independent variable and the 
dependent variable was 0.365 . It meant that the customer trust as an intervening variable could be proved as the intervening variable because the total value of the indirect correlation of the independent variable $X$ through the intervening variable $Y 2$ and then to the dependent variable $(Z)$ was 0.365 which was greater than the direct correlation of the independent variable $(X)$ to the dependent variable $(Z)$ of 0.331 .

\section{DISCUSSION OF RESULTS}

The aims of the research conducted by the researcher was to test each indicator of service quality effect on customer loyalty with customer satisfaction and customer trust as the intervening variables at PT Bank Tabungan Negara represented by Surabaya Branch Office as the research sample. Based on the results of the first hypothesis testing, the service quality had a direct effect on customer loyalty that obtained the positive and significant result. Thus, the service quality did have a direct positive effect on customer loyalty. Maximum service that was as much as possible beyond what was expected by the customer would have a great effect on the loyalty of the customers to keep using the existing products of the bank.

In a research conducted by $\mathrm{Ngo}$ and Nguyen (2016), it was true that the effect of the service quality provided by a bank to its customers has a great effect on the customer's ability to maintain their loyalty to use the banking products they already have before. The better the quality service provided by a bank then the loyalty level of the customer will increase in a straight direction. From the transformation carried out by BTN, it became the best bank with the third rank and BTN continued to provide the best service to its customers. As the evidence, it held the Best Front-liner Award event every year starting from the Branch Office and would be implemented centrally at BTN Headquarters in Jakarta after getting the best representative from the Branch Office. It was also an effort of BTN to always improve the service quality given by their employees which would affect the loyalty of its customers.

The result of second hypothesis testing of this research was about the effect of service quality to customer loyalty with customer satisfaction as the mediator. It obtained the result that the direct effect of customer service to customer loyalty was greater than the indirect effect. The result of indirect effect of service quality on customer loyalty mediated by customer satisfaction obtained smaller result. Thus, it could be explained that the customer satisfaction was not necessarily followed by the establishment of customer loyalty. From the open questions given by the researcher to the respondent in the questionnaire, it was found that the customer was satisfied with the service provided by BTN but it was more dominated by the answer that the customers use or open the BTN account only for Housing Credit (KPR) transaction. Once the mortgage liabilities of the client were fully paid, then the existing account in BTN would mostly be left without any transaction or it would become a passive account. There were answers to the limitations of BTN ATMs that were still rare in Surabaya compared to other banking competitors such as BRI, Mandiri and BNI. It had made the variable of customer satisfaction to have little effect on customer loyalty.

The result of the third hypothesis testing was about the effect of service quality on customer loyalty with customer trust as the intervening variable. It obtained the result that the indirect effect generated by the customer trust as a mediator was greater or it obtained a significant and positive result which was greater than its direct effect. Mian (2014) mentioned that the presence of customer trust greatly determined customer loyalty in the future. An important factor affecting customer loyalty was the high level of customer trust to the bank. Thus, it could be said that customer trust was indeed a factor that could affect customer loyalty from the service quality provided by a bank.

Implications of research findings. The findings of this research can be used as a reference for decision making in the future. The variables under the research concern about service quality, customer satisfaction, customer trust, and customer loyalty. The findings of this research can also be used as a useful input for the internal management of PT Bank Tabungan Negara Tbk in general and Bank Tabungan Negara of Surabaya Branch Office in particular, which became the setting of the research. In accordance with the transformation 
efforts undertaken by BTN, as a bank that could be aligned with other banks, BTN should get a lot of inputs that can be used as a reference to support the process of those efforts.

With the achievement of good service quality provided by BTN, it can be used as a strategic plan by the company to become better and increase customer loyalty to BTN. In addition, with increased levels of customer satisfaction and customer trust then BTN will be able to achieve its goals smoothly. Due to the increasingly tight banking business competition in Indonesia, BTN is required to be able to catch up what it has not performed. With the improvement of service in terms of physical and non-physical improvement performed by Bank BTN, it was also expected to increase customer satisfaction and also customer trust that can positively affect customer loyalty so they are more loyal to BTN.

Based on the findings of this research, the company is expected to know the gap that can be used to improve the provided service quality and also as one way for the company to be able to develop the aspect of customer service in order to increase the level of customer satisfaction, customer trust and customer loyalty that will directly affect the consistency of BTN in the future to become better and more advanced.

\section{CONCLUSION}

In the banking world, the customer is a major asset whose comfort and security should always take precedence. By improving the service quality, it would be very useful to support the level of customer satisfaction which would also affect the customer trust as well as customer loyalty as the final estuary of the achievement of success in retaining the customers. The high level of customer loyalty would show the existence of a bank in the banking business competition which was increasingly tight day after day. All banks were competing to provide the best possible customer service which would make their customers felt comfortable and eventually became loyal to the bank. This was also carried out to attract new customers with a good level of service provided by the bank.

Based on the research findings, it was found that the service quality had a direct effect with the significant and positive results on customer loyalty that could be used by BTN as a reference to further maintain and further improve its services. Customer satisfaction, in this research, could not be used as a benchmark of customer loyalty due to several reasons that might produce different results; depending on the objects of the conducted research. Customer of BTN of Surabaya Branch Office commonly felt satisfied with the provided services. However, the satisfaction was derived from the service quality so that customer loyalty in this research showed insignificant result. This might be due to the reason that the customers had BTN account only for mortgage requirements. Meanwhile, the effect of service quality on customer loyalty mediated by customer trust showed significant and positive result which meant that the trust obtained from good service quality provided by BTN of Surabaya Branch Office truly gave positive effect on customer loyalty.

Limitations of the research. This research had been pursued and carried out in accordance with scientific procedures, however it still had limitations including: 1) the respondents used in this research were only the customers who owned savings account at BTN of Surabaya Branch Office, 2) the research conducted only analyzed the effect of service quality, satisfaction and customer trust and customer loyalty at PT Bank Tabungan Negara of Surabaya Branch Office Tbk.

\section{REFERENCES}

1. Akbar, M. M., \& Parvez, N. (2009). Impact of service quality, trust, and customer satisfaction on customers loyalty. ABAC Journal, 29(1).

2. Ariyani, F. (2008). Membangun Loyalitas Nasabah Melalui Peningkatan Kualitas Pelayanan dan Keunggulan Produk (Studi Empiris Pada PT. Bank Bukopin Tbk di Kota Semarang)(Doctoral dissertation, Program Pasca Sarjana Universitas Diponegoro). 
3. Bedi, M. (2010). An Integrated Framework for Service Quality, Customer Satisfaction and Behavioral Response in Indian Banking Industry - a Comparison of Public and Private, Journal of Services Research, 10(1).

4. Hair, J. F., Black, W. C., Babin, B. J., Anderson, R. E., \& Tatham, R. L. (2006). Multivariate data analysis (Vol. 6).

5. Hermansyah, Hukum Perbankan Nasional Indonesia, Ditinjau menurut Undang - undang No. 7 tahun 1992 tentang Perbankan sebagaimana telah diubah dengan Undang undang No. 10 tahun 1998 dan Undang - undang No. 23 tahun 1999 jo Undang undang No. 3 tahun 2004 tentang Bank Indonesia, Kencana, Jakarta, Edisi Revisi, Cetakan Kelima, 2009

6. Kasmir, (2004). Bank dan Lembaga Keuangan Lainnya. Jakarta : PT. Raja Grafindo Persada

7. Mian, T. S. (2014). The Role of Service Quality in Developing Customer Loyalty in the Banking Sector: A Case study of the Kingdom of Saudi Arabia. International Journal of Accounting and Financial Reporting, 4(2), 339-360.

8. Ngo, V.M., \& Nguyen, H.H. (2016). The Relationship Between Service Quality, Customer Satisfaction and Customer Loyalty: An Investigation in Vietnamese Retail Banking Sector. Journal of Competitiveness, 18(4), 103-116

9. Sugiyono. 2012. Metode Penelitian Kuantitatif, Kualitatif dan R\&D. Bandung : Alfabeta.

10. Suhardi, G. 2006. Faktor - Faktor Yang Mempengaruhi Kepercayaan dan Loyalitas Nasabah Perbankan di Surabaya, Jurnal Kinerja, 10(1), hal. 50-56

11. Suryani, T. 2008. Perilaku Konsumen: ImplikasiPada Strategi Pemasaran, Yogyakarta: Graha IImu 